\title{
1. Navigating law and religion: familiar waterways, rivers less travelled and uncharted seas
}

\author{
Rex Ahdar
}

\section{INTRODUCTION}

Since this is a research handbook I think it behoves me to attempt to map the terrain or to change the metaphor - the ocean that constitutes Law and Religion.

Some topics are well traversed. The familiar and well-serviced waterways include major catchments such as the right of religious freedom and the constitutional arrangements between a state and the major organized religions within that jurisdiction. I will canvass these briefly in section 2 .

Other subjects are not novel but simply seldom covered, and section 3 will select several of these. The minor tributaries and backwaters are charted but not commonly explored in any great breadth or depth. Here one thinks of indigenous religions and spiritual concerns, and perhaps the extremities of religious practice such as exorcism or witchcraft. Despite the 'proliferation'1 and 'immense body'2 of work now being published in the field, the deeper jurisprudential interaction between law and religion remains a less travelled river. ${ }^{3}$

Then there are what I would call completely uncharted seas. This might fill one with dread, or hope. As for the latter, Friedrich Nietzsche enthused:

Indeed, at hearing the news that the 'old God is dead', we philosophers and 'free spirits' feel illuminated by a new dawn; our heart overflows with gratitude, amazement, forebodings, expectation - finally the horizon seems clear again, even if not bright; finally our ships may set out again, set out to face any danger; every daring of the lover of knowledge is allowed again; the sea, our sea, lies open again; maybe there has never been such an 'open sea'. ${ }^{4}$

1 Mark Hill, 'The Changing Landscape of Law and Religion in Europe: Secularism and Cultural Heritage' (2016) 31 J of Law \& Religion 321, 332.

2 Marie A Failinger, 'Twenty-Five Years of Law and Religion Scholarship: Some Reflections' (2014) 30 Touro L Rev 9, 9.

3 '[I]ncreasing interest in the relationship between law and religion has led to an exponential increase in the amount of scholarship concerning these matters. However, the literature reflects a number of gaps, most notably in the area of jurisprudence. Indeed, comprehensive, cross-border theoretical analyses of religio-legal concerns are virtually nonexistent': SI Strong, Transforming Religious Liberties: A New Theory of Religious Rights for National and International Legal Systems (Cambridge, Cambridge University Press, 2018) 7.

4 Aphorism 343, Book Five, We Fearless Ones in Nietzsche's, The Gay Science (original 1882; Bernard Williams (ed); translation by Josefine Nauckhoff; Cambridge, Cambridge University Press, 2001) 199 (italics in original). 
For theists, the 'open sea' is (humanly speaking) daunting, but also an opportunity to test one's faith under the guiding light of Providence. 5 Would we possess the firm confidence of a Blaise Pascal: 'There is some pleasure in being on board a ship battered by storms when one is certain of not perishing' ${ }^{6}$

In section $4 \mathrm{I}$ will indulge myself in some speculation and amateur futurology. I will assume the mantle of a sort of latter-day Vasco da Gama or James Cook, albeit never leaving my office. Predictions are always difficult, especially as to the future, ${ }^{7}$ but I will use a long-range telescope to ponder what strange phenomena may one day confront scholars in the law and religion seven seas. Finally, in section 5 I offer a few concluding thoughts. ${ }^{8}$

\section{FAMILIAR WATERWAYS}

To read a book on Law and Religion (in that order) ${ }^{9}$ in an English-speaking nation is to see a discussion and analysis of church-state relations, the secularity (or otherwise) of the state, the nature of the established religion (if any), the right of religious freedom and the laws prohibiting religious discrimination. Marie Failinger terms these 'the central questions of traditional law and religion studies'. ${ }^{10}$

When I first entered this field, there was no sub-discipline called 'Law and Religion'. There is still some debate as to whether there is such a thing today, ${ }^{11}$ but I think it safe to say that it is now moderately well-embedded in law school curricula, scholarly networks and legal publishers' catalogues. On the definitional question, Russell Sandberg observed:

law and religion - the general study of how law and religion interact - may be best understood as including both the study of two complementary and overlapping elements. The first is religion law, the 'external' temporal, spiritual laws made by the State (and international bodies, and sub-State institutions) which affect religious individuals and groups. The second is religious law, the 'internal' laws or other regulatory instruments made by

5 On divine providence see Joseph B Soloveitchik, Halakhic Man (translation by Lawrence Kaplan; Philadelphia, Jewish Publication Society, 1983) 123-128.

6 Pascal Pensées (trans by AJ Krailsheimer) (Harmondsworth, Penguin Books, 1996). This is the first half of Pascal's Pensée number 743.

7 Lawrence Peter 'Yogi' Berra (1925-2015), legendary New York Yankees' baseball catcher and expounder of quirky sayings: quoted in, eg, 'The Perils of Prediction', The Economist, 31 May 2007.

8 I have not undertaken the usual practice of summarizing and briefly commenting upon each of the essays in this volume. This has always struck me as a rather redundant, if not stultifying, exercise.

9 If one's priority was religion not law, then it might take the form of a book such as that by Peter W Edge, Religion and Law: An Introduction (Aldershot, Ashgate, 2006).

10 Failinger, 'Twenty-Five Years of Law and Religion Scholarship', 10-11.

11 See Russell Sandberg, Law and Religion (Cambridge, Cambridge University Press, 2011) ch 1 . 


\section{Research handbook on law and religion}

religious groups themselves which affect not only the members of these groups, but also how those groups interact with the State. ${ }^{12}$

In terms of publications, turning to the United Kingdom, there were but a few titles: St John Robilliard's Religion and the Law ${ }^{13}$ and Francis Lyall's Of Presbyters and Kings. ${ }^{14}$ To that can be added Anthony Bradney's incisive short volume, Religion, Rights and Laws. ${ }^{15}$ The Commonwealth countries similarly had few books - a rare example being Canadian scholar, Margaret Ogilvie's Religious Institutions and the Law. ${ }^{16}$

In the United States, there was, by contrast, a veritable glut of riches, centred naturally enough around the Religion Clauses of the First Amendment. One that stood out for me for its attempt to explain the relationship between the law and religion was Harold Berman's wonderful short monograph, aptly entitled The Interaction of Law and Religion. ${ }^{17}$

Aside from case books, there was a large corpus of critical works that sought to describe and prescribe the history and present relationship between American government and religion. An excellent example of a modern treatment of US law is Kent Greenawalt's two-volume treatise published in 2006. ${ }^{18}$ Quite apart from books, there are the multitude of long, book-length(!) articles that adorn the many American law reviews. A couple that spring to mind are Michael McConnell's magisterial article on the origins of the Free Exercise Clause and Stanley Fish's penetrating 'Mission Impossible: Settling the Just Bounds between Church and State'. ${ }^{19}$

Returning to the United Kingdom, the field was transformed following the enactment of the Human Rights Act 1998, which incorporated the European Convention on Human Rights and Freedoms into British law. It is interesting that one of the more contentious matters in the 1998 Act was the extent to which organized religious bodies would have to comply with the Convention. This spawned s 13 of the Act, which requires courts to pay 'particular regard' to a religious organization's exercise of its

12 Ibid, 10. For further analysis, see Russell Sandberg's chapter in this book (ch 2).

13 Religion and the Law: Religious Liberty in Modern English Law (Manchester, Manchester University Press, 1984).

14 Of Presbyters and Kings: Church and State in the Law of Scotland (Aberdeen, Aberdeen University Press, 1980).

15 Religion, Rights and Laws (Leicester, Leicester University Press, 1993).

16 Religious Institutions and the Law (Scarborough, Ontario, Carswell 1996). It is now up to its 4th edition (Toronto, Irwin Law, 2017).

17 The Interaction of Law and Religion (Nashville, Abingdon Press, 1974).

18 Religion and the Constitution: Volume 1, Free Exercise and Fairness (Princeton, Princeton University Press, 2006); Religion and the Constitution: Volume 2, Establishment and Fairness (Princeton, Princeton University Press, 2006).

19 Michael W McConnell, 'The Origins and Historical Understanding of Free Exercise of Religion' (1990) 103 Harvard L Rev 1409. The article is 108 pages long. Fish's article is found in (1997) 97 Columbia L Rev 2255 and is 78 pages long. 
right to freedom of thought, conscience and religion. ${ }^{20}$ In practice, the section has proved to be something of a damp squib. ${ }^{21}$

The familiar waterways, as already mentioned, are religious freedom and religionstate relations. Streams and tributaries flowing into these are the evaluation of and justiciability of religious claims by civil tribunals; ${ }^{22}$ the legal definition of 'religion'; religious hate speech and vilification; blasphemy laws; clergy-penitent privilege; ${ }^{23}$ conscientious objection in medical and military spheres; ${ }^{24}$ religious education and indoctrination; prayers in legislatures, council meetings, universities and schools; disputes over ecclesiastical buildings and property following schism; and so on.

Of late, many of the most interesting discussions have focused upon the tension between equality norms and religious freedom, and there are some very good works analysing the case law and its implications. ${ }^{25}$

For those completely new to the field and for seasoned veterans I will risk alienating colleagues and friends by attempting a WatchMojo-like 'Top 10' of the leading scholars in Law and Religion. These would be ideal navigators to stand alongside one on the ship's bridge. This is, of course, a terribly subjective compilation and, furthermore, it is restricted to those who are currently active and who write in English. With such caveats in mind, here it is:

1. Michael McConnell (Stanford)

2. John Witte Jr (Emory)

3. Steven D Smith (San Diego)

4. Kent Greenawalt (Columbia)

5. Douglas Laycock (Virginia)

6. Ian Leigh (Durham)

7. Paul Horwitz (Alabama)

8. Frederick Gedicks (Brigham Young)

9. Lawrence Sager (Texas)

10. Norman Doe (Cardiff)

20 See Julian Rivers, 'From Toleration to Pluralism: Liberty and Religious Establishment under the United Kingdom's Human Rights Act' in Rex Ahdar (ed), Law and Religion (Aldershot, Ashgate, 2000) ch 7.

21 See James Dingemans et al., The Protections for Religious Rights: Law and Practice (Oxford, Oxford University Press, 2013) [5.31]: 'Section 13 has not affected the outcome of any decided case involving freedom of religion and is often given short shrift when raised in argument'.

22 As to which, see the essays by Michael Helfand (ch 13) and Francois Venter (ch 14) in this collection.

23 See Keith Thompson's chapter (ch 21) in this volume.

24 See further the chapter by Ian Leigh (ch 18) in this handbook.

25 Aside from the chapter by Steve Smith in this volume (ch 3), see, eg, Roger Trigg, Equality, Freedom, and Religion (Oxford, Oxford University Press, 2012); Joel Harrison and Patrick Parkinson, 'Freedom Beyond the Commons: Managing the Tension between Faith and Equality in a Multicultural Society' (2014) 40 Monash UL Rev 413; W Cole Durham Jr and Donlu Thayer (eds), Religion and Equality: Law in Conflict (London, Routledge, 2016) and, earlier, Christopher Eisgruber and Lawrence Sager, Religious Freedom and the Constitution (Cambridge, MA, Harvard University Press, 2007). 
In the 'honourable mentions' list goes (in no set order) Julian Rivers, Cole Durham Jr, Peter Edge, Andrew Koppelman, Mark Hill, Perry Dane, Abner Greene, Russell Sandberg and Carolyn Evans. Of the rising 'stars' I think of Michael Helfand, Kathleen Brady, Ronan McCrea, Lorenzo Zucca, Joel Harrison and Stacie Strong.

\section{RIVERS LESS TRAVELLED}

There is a litany of largely unrelated subjects that, in my opinion, receive insufficient attention. These include law and religion concerns in major non-Christian faiths such as, for instance, Buddhism, ${ }^{26}$ and feminist law and religion analyses. ${ }^{27} \mathrm{I}$ have selected three areas that merit separate mention.

\subsection{Indigenous Religion}

A fascinating area of law and religion is the relationship between indigenous peoples and the law of the land. ${ }^{28}$ There have been a number of disputes in Canada, the US, Australia and New Zealand where the aboriginal tribes or communities have opposed projects that would, in their view, desecrate land, mountains, rivers, creatures, and so on, that they hold sacred. It is fair to say secular courts and tribunals have tried to understand and give due weight to the spiritual concerns of the indigenous claimants, but where an impasse is reached, and no semblance of reasonable compromise forthcoming, the verdict has usually gone against the local tribe. This is an area of scholarship that in my view has been neglected. ${ }^{29}$ This is a shame, for it offers a rich harvest.

26 See, nonetheless, Rebecca R French, 'A Conversation with Tibetans? Reconsidering the Relationship between Religious Beliefs and Secular Discourse' (2001) 26 Social Inquiry 95 and the special issue of the Buffalo Law Review in 2007: 'Law, Buddhism and Social Change' (2007) 55 (2) Buffalo L Rev 639.

27 See Noemi Gal-Or, 'Is the Law Empowering or Patronizing Women? The Dilemma in the French Burqa Decision as the Tip of the Iceberg' (2011) 6 Religion \& Human Rights 315; Marie A Failinger, Elizabeth R Schiltz and Susan J Stabile (eds), Feminism, Law, and Religion (Farnham, Ashgate, 2013). See also the chapter by Renae Barker in this book (ch 19).

28 See generally Rex Ahdar, 'Indigenous Spiritual Concerns and the Secular State: Some New Zealand Developments' (2003) 23 Oxford J Legal Stud 611.

29 For the sparse writing on the subject see, for New Zealand, Ahdar, ibid; Fiona Wright, 'Law, Religion and Tikanga Maori' (2007) 5 NZ J of Public \& Int'l Law 261. For Australia, see Aliza Taubman, 'Protecting Aboriginal Sacred Sites: The Aftermath of the Hindmarsh Island Dispute' (2002) 19 Envir \& Planning LJ 140; Ernst Wilheim, 'Australian Legal Procedures and the Problem of Secret Aboriginal Spiritual Beliefs: A Fundamental Conflict' in Peter Cane, Carolyn Evans and Zoe Robinson (eds), Law and Religion in Theoretical and Historical Context (Cambridge, Cambridge University Press, 2008) ch 10. Regarding the Canadian experience, see Lori Beaman, 'Aboriginal Spirituality and the Legal Construction of Freedom of Religion' (2002) 44 J of Church \& State 135; John Borrows, 'Living Law on a Living Earth: Aboriginal Religion, Law and the Constitution' in Richard Moon (ed), Law and Religious Pluralism in Canada (Vancouver, UBC Press, 2008) ch 7. For the US, see Carolyn N Long, Religious Freedoms and Indian Rights: The Case of Oregon v Smith (Lawrence, University Press of 
The latest case is Ktunaxa Nation v British Columbia (Minister of Forests, Lands and Natural Resource Operations). ${ }^{30}$ The Ktunaxa First Nation live, inter alia, in an area of British Columbia they call Qat'muk. This place is of spiritual significance for the Ktunaxa: 'it is home to an important population of grizzly bears and the Grizzly Bear Spirit or Klawa Tuklulak, "a principal spirit within Ktunaxa religious beliefs and cosmology". ${ }^{31}$ Glacier Resorts sought to construct a year-round ski resort in the upper Jumbo Valley within Qat'muk. For this it required government approval, and the relevant Minister - after a 'deep' 32 and protracted 20-year consultation (1991 to 2011) with the Ktunaxa on the spiritual claim - gave this. This did not go well with the First Nation, who steadfastly maintained that 'accommodation was impossible because the ski resort with lifts to glacier runs and permanent structures would drive Grizzly Bear Spirit from Qat'muk and irrevocably impair their religious beliefs and practices'. ${ }^{33}$

Here was yet another classic instance of indigenous spiritual beliefs confronting land development. Based on cases of this sort, if I had been asked to predict the outcome I would have said the judgment would see many fine placating words said about how the spiritual beliefs were genuine and weighty and had been indeed duly taken into account but, regrettably, the project would be approved. And so it would prove.

The majority of the Supreme Court held that the religious freedom guarantee in the Charter (s 2(a)) had not even been infringed. In a passage that is, with respect, as puzzling as it is naïve, McLachin CJ and Rowe J stated:

The state's duty under s 2(a) is not to protect the object of beliefs, such as Grizzly Bear Spirit. Rather, the state's duty is to protect everyone's freedom to hold such beliefs and to manifest them in worship and practice or by teaching and dissemination. In short, the Charter protects the freedom to worship, but does not protect the spiritual focal point of worship. We have been directed to no authority that supports the proposition that s 2(a) protects the latter, rather than individuals' liberty to hold a belief and to manifest that belief. Section 2(a) protects the freedom to pursue practices, like the wearing of a kirpan in Multani or refusing to be photographed in Alberta v Hutterian Brethren of Wilson Colony. ... And s 2(a) protects the right to freely hold the religious beliefs that motivate such practices. In this case, however, the appellants are not seeking protection for the freedom to believe in Grizzly Bear Spirit or to pursue practices related to it. Rather, they seek to protect Grizzly Bear Spirit itself and the subjective spiritual meaning they derive from it. That claim is beyond the scope of s 2 (a). ${ }^{34}$

Kansas, 2000); James Youngblood Henderson, 'The Struggle to Preserve Aboriginal Teaching and Practices' in John McLaren and Harold Coward (eds), Religious Conscience, the State and the Law (Buffalo, SUNY Press, 1999) ch 11; Thomas C Maroukis, The Peyote Road: Religious Freedom and the Native American Church (Norman, University of Oklahoma Press, 2010); John Wunder (ed), Native American Cultural and Religious Freedoms (original 1999; New York, Routledge, 2013), Nicholas Howe, Landscapes of the Secular: Law, Religion, and American Sacred Space (Chicago, University of Chicago Press, 2016).

302017 SCC 54. For further analysis, see Benjamin Berger in chapter 10 of this volume.

312017 SCC 54, [5].

32 Ibid, [48], [87], [105].

33 Ibid, [6].

34 Ibid, [71]. Five other justices concurred. 


\section{Research handbook on law and religion}

If religious liberty does not extend to the 'spiritual focal point of worship' then it is difficult to see that it amounts to very much. Destroy the object of worship and surely you have destroyed the religion. One can still stubbornly cling to the memory of the mountain, lake or forest, but if that is gone and one's deity (small 'd') has lost its home, then what is left? You would be left trying to believe and practice rituals knowing that the deity had been evicted or at least relocated to another land. The minority Justices agreed, and on this point (but not the overall result), Moldaver and Côté JJ, quite rightly found there was an infringement of the tribe's religious liberty:

The development of the ski resort would desecrate Qat'muk and cause Grizzly Bear Spirit to leave, thus severing the Ktunaxa's connection to the land. As a result, the Ktunaxa would no longer receive spiritual guidance and assistance from Grizzly Bear Spirit. All songs, rituals, and ceremonies associated with Grizzly Bear Spirit would become meaningless. ... The Minister's decision to approve the ski resort will render all of the Ktunaxa's religious beliefs related to Grizzly Bear Spirit devoid of any spiritual significance. Accordingly, the Ktunaxa will be unable to perform songs, rituals or ceremonies in recognition of Grizzly Bear Spirit in a manner that has any religious significance for them. In my view, this amounts to a s 2(a) breach. ${ }^{35}$

Whilst the Ktunaxa succeeded on that point, the Court was unanimous that the Minister had correctly (and proportionately) balanced the tribe's religious freedom right with the duty to administer Crown land for the public interest. The Minister had made strenuous efforts to accommodate the Ktunaxa's spiritual concerns, ${ }^{36}$ albeit these were insufficient for the latter - there being, as the Court repeatedly commented, 'no middle ground' 37 available here. To accede to the tribe's wishes would be to effectively allow them to veto development over a significant tract of land (over 50 square kilometres). It was not appropriate 'for a religious group [to] be able to regulate the use of a vast expanse of public land so that it conforms to its religious belief'. ${ }^{38}$ Undeterred, the Ktunaxa Nation Council declared it would fight on. ${ }^{39}$ I will conclude this short section with a pungent comment by Greenawalt:

If Christians believed Jesus was crucified in South Dakota rather than Jerusalem, on land now owned by the government, Christians would be shocked if the government proposed to build a gambling casino on the site. ${ }^{40}$

35 Ibid, [117]-[118].

36 See ibid, [28] and [145].

37 Ibid, [36], [149], [153]. Similarly, it referred to the Ktunaxa's 'uncompromising' stance: ibid, [6], [43]. It probably did not help that the other First Nation, the Shuswap, did support the ski resort on the basis it would provide good opportunities for their community: ibid, [14], [150].

38 Ibid, [152].

39 Sunny Dhillon, 'B.C. First Nation Officials See Jumbo Glacier Ski Resort Ruling as Failing of Top Court', Globe and Mail, 2 November 2017.

40 Greenawalt, Religion and the Constitution: Volume 1, Free Exercise and Fairness, ch 12, 193. 


\subsection{Exotic Religious Practices and the Rise of Neo-paganism}

A congeries of exotic, bizarre, or just plain extreme religious practices or rituals await further analysis. Of course, the provocative epithets I have just used are loaded. Conduct that appears from a secular, rational, scientific stance - or even a 'mainstream' religious position - strange or odd is, from within the community that has such beliefs and engages in such conduct, entirely normal and commonplace. What I have in mind here are practices such as exorcism, fortune telling, séances, witchcraft and ritual healing. ${ }^{41}$

In an age of state neutrality towards religion, belief and conscience these kinds of spiritual conduct cannot be banned per se. 'One person's "witchcraft" is another person's religion' ${ }^{42}$ as two Canadian scholars put it. What to orthodox Christians and other theists is nothing more than pernicious occult activity is, and must be, permitted within a liberal democratic state.

There have been some interesting recent cases on exorcism ${ }^{43}$ that have been critiqued mainly by criminal law scholars. ${ }^{44}$ Their preoccupation, naturally enough, is with the niceties of consent by the unfortunate recipients of exorcisms that went awry.

The other category of under-researched study is what I will call neo-Paganism. By this I mean the resurgence of revitalized versions of ancient religions. One writer suggests a tripartite division:

Today in both American and British pagan circles practitioners generally divide themselves into three basic groups: Wiccans; Druids and those who follow some kind of Celtic religion; and Heathens, those who follow Germanic and Norse traditions. Heathens call themselves by this name for two main reasons. Firstly, they prefer the word (derived from 'heath', a wild part of the landscape, so similar to pagan, meaning 'from the remote countryside') as it is an indigenous term used by the northern peoples themselves as opposed to pagan, which is

41 On séances, fortune telling and mediums, see Peter W Edge, 'Naturalism and Neutrality: Trying Miraculous Claims Fairly in English Courts' (2002) 44 J of Church \& State 521 and Steve Greenfield, Guy Osborn and Stephanie Roberts, 'From Beyond the Grave: The Legal Regulation of Mediumship' (2012) 8 Int'l J of Law in Context 97.

42 Natasha Bahkt and Jordan Palmer, 'Modern Law, Modern Hammers: Canada's Witchcraft Provision as an Image of Persecution' (2015) 35 Windsor Review of Legal \& Social Issues 123, 136.

43 In New Zealand, aside from the prominent Court of Appeal case, $R v$ Lee [2006] 3 NZLR 42 , there is the (similarly) tragic case, $R v$ Rawiri, High Court, Wellington, CRI 2007-032-5294 (14 August 2009). In Rawiri, five family members were convicted of the manslaughter of their 22-year-old niece after a prolonged ritual to lift a curse (makutu) from their relative ended in her death: see further 'No Appeal Over Exorcism Sentences', New Zealand Herald, 18 August 2009. For a fascinating US case, see In re Pleasant Glade Assembly of God, 991 S W 2d 85 (Tex App, Fort Worth 1998) (free exercise of religion defence to an action for discovery by parents of a youth attending the Assembly of God church to sue for 'casting out demons' ceremony involving their 17-year-old daughter).

44 See, eg, Helen Hall, 'Exorcism, Religious Freedom and Consent: The Devil in the Detail' (2016) 80 J of Criminal Law 241. 
derived from the Latin. Secondly, it distinguishes them from other pagans whose ideas, beliefs and practices may be very different. ${ }^{45}$

Whilst there have been a reasonable, albeit sporadic, number of cases where the beliefs and practices of this eclectic group of nature-based religions have been scrutinized, the associated commentary or critique has not been commensurate. ${ }^{46}$ How interesting, for instance, to have had legal commentary on the Wiccan practitioner who defended his arrest for carrying a five-inch blade knife in public on the ground he needed it, as a warlock, for ritual purposes. ${ }^{47}$

\subsection{Law as a Religious Enterprise}

Here I take the title from a typically original and brilliant essay by Steve Smith. ${ }^{48}$ To ask to what extent, if at all, law is a religious enterprise, or can be said to have an implicit faith (in its sacred texts and authoritative sources), is to return to the 'big' questions that Harold Berman, Eric Voegelin ${ }^{49}$ and Roscoe Pound ${ }^{50}$ asked over a generation or more ago. It is to once more consider what is the relationship between law and religion. ${ }^{51}$ From those of us on the law side of the academy, it is to ponder again not just the religious roots of modern law, ${ }^{52}$ but the unarticulated, subterranean, if not downright mysterious, ways that religious concepts, ideals, language, virtues,

45 Richard Rudgley, Pagan Resurrection: A Force for Evil or the Future of Western Spirituality? (London, Century, 2006) 239.

46 A rare example is the chapter devoted to 'Paganisms' in Peter W Edge, Legal Responses to Religious Difference (The Hague, Kluwer Law, 2002) ch 11. See also BS Stewart, 'Opening the Broom Closet: Recognizing the Religious Rights of Wiccans, Witches, and Other NeoPagans' (2011) 32 N Illinois U L Rev 135.

47 'Warlock Allowed to Break Curfew for Full Moon', Daily Telegraph, 10 March 2011.

48 Steven D Smith, 'Law as a Religious Enterprise: Legal Interpretation and Scriptural Interpretation' in Richard O'Dair and Andrew Lewis (eds), Law and Religion: Current Legal Issues 2001, Vol 4 (Oxford, Oxford University Press, 2001) 83. See also Steven D Smith, 'Believing Like a Lawyer' (1999) 40 Boston College L Rev 1041; Steven D Smith, Law's Quandary (Cambridge MA, Harvard University Press, 2004).

49 See the anthology containing many essays highlighting Voegelin's thought in Bart C Labuschagne and Reinhard W Sonnenschmidt (eds), Religion, Politics and the Law: Philosophical Reflections on the Sources of Normative Order in Society (Leiden, Brill, 2009).

50 Roscoe Pound, Law and Religion (Houston, Rice Institute, 1940) (The Rockwell Lectures on Religious Subjects, delivered at the Rice Institute, 2-4 April, 1940).

51 More recently, see, eg, Timothy Fort, Law and Religion (Jefferson NC, McFarlane \& Co Publishers, 1987); Gad Barzilai, 'Introduction' in Gad Barzilai (ed), Law and Religion (Aldershot, Ashgate, 2007) xi (I have listed Barzilai as the author, but there is no clear attribution in the book); Bart Labuschagne, 'Religion and Order: Philosophical Reflections from Augustine to Hegel on the Spiritual Sources of Law and Politics' in Labuschagne and Sonnenschmidt (eds), Religion, Politics and the Law, ch 3. For a rather eccentric view of the subject, see Philip R Wood, The Fall of the Priests and the Rise of the Lawyers (Oxford, Hart, 2016).

52 See, eg, Jacques Ellul, The Theological Foundation of Law (trans Marguerite Wieser) (original 1946; London, SCM Press, 1961) and, of course, the writings of Berman: see The Interaction of Law and Religion and Harold J Berman, Faith and Order: The Reconciliation of Law and Religion (Atlanta, Scholars Press, 1993). 
modes of thought, hermeneutics, and so on, continue to exert their influence. ${ }^{53}$ This is not scholarship for the faint hearted. As Benjamin Berger rightly comments (in what is an outstanding contemporary example of the thing I am taking about):

The meeting of law and religion is not, at heart, a juridical or technical problem to be addressed by better laws; rather, it is profitably understood as an instance of cross-cultural interaction, and, as such, endlessly unstable and provocative. ${ }^{54}$

I was intrigued to see that the last book ever published by arguably the leading legal philosopher of his generation, Ronald Dworkin, was entitled Religion Without God. ${ }^{55}$ This tiny book contained the manuscript of his Einstein Lectures, which he gave in 2011. It would have been fascinating to see what his brilliant mind would have achieved had his death in early 2013 not cut short his plan to 'extend his treatment of the subject' over the ensuing years. ${ }^{56}$

\section{UNCHARTED SEAS}

The very attempt to predict the future is either dismissed as absurd or futile by some, or approached with a measure of cautious excitement, by others. In keeping with my maritime theme, I stumbled across this apposite sentence in the absorbing futurological bestseller, Homo Deus, where Yuval Noah Harari expresses some trepidation: 'We are akin to the inhabitants of a small isolated island who have just invented the first boat, and are about to set sail without a map or even a destination'. ${ }^{57}$ Others are not so pessimistic. Brian Cox believes that, 'We are able to predict our future with increasing certainty' and that 'science and reason make the darkness visible'.58

The concern of most futurologists is with the economy, environment, scientific and technological progress, geopolitical structures or religion. ${ }^{59}$ To speculate on the future shape of the relationship between Law and Religion then I will seek to collect the

53 For a fine discussion, see the essay by Jonathan Burnside in this volume (ch 4).

54 Benjamin L Berger, Law's Religion: Religious Difference and the Claims of Constitutionalism (Toronto, University of Toronto Press, 2015) 18. Another excellent recent example is Stacie Strong's Transforming Religious Liberties, which develops a theoretical framework based upon 'the religiously oriented original position'.

55 Religion Without God (Cambridge, MA, Harvard University Press, 2013). For a detailed critique, see Joel Harrison, chapter 5 of this book.

56 According to the Publisher's Note: Religion Without God, ix.

57 Yuval Noah Harari, Homo Deus: A Brief History of Tomorrow (London, Harvill Secker/Vintage, 2016) 353.

58 Brian Cox and Andrew Cohen, Human Universe (London, William Collins, 2015) 214.

59 On technology, see, eg, Martin Ford, The Rise of the Robots: Technology and the Threat of Mass Unemployment (London, Oneworld, 2015). For economics, see, eg, Paul Mason, PostCapitalism: A Guide to Our Future (London, Penguin, 2016). On geopolitics, see, eg, Moisés Naím, The End of Power (New York, Basic Books, 2013) and Slavoj Zizek, Living in the End Times (rev edn, London, Verso, 2010). Regarding religion, see, eg, Lloyd Geering, The World to Come: From Christian Past to Global Future (Wellington, Bridget Williams Books, 1999). 


\section{Research handbook on law and religion}

'crumbs from the table', ${ }^{60}$ as it were, of those who explain the rise of artificial intelligence, robotics, nanotechnology and the like.

I will turn first to religion. Harari actually has a reasonable amount to say about this. By religion he means 'anything that confers superhuman legitimacy on human social structures [and] legitimises human norms and values by arguing that they reflect superhuman laws'. ${ }^{61}$ Harari makes some bold if familiar claims: humans have no soul, ${ }^{62}$ nor do they enjoy free will; ${ }^{63}$ God is redundant; 64 life has no meaning or grand plan. ${ }^{65} \mathrm{He}$ also advances some less familiar ones: humans will achieve extended lifespans, if not near immortality, ${ }^{66}$ and man is an organism made of algorithms. ${ }^{67}$

Nonetheless, Harari does see the prospect of new religions emerging. These 'new techno-religions may conquer the world by promising salvation through algorithms and genes'. ${ }^{68}$ One type will be 'techno humanism', the progress from Homo sapiens to Homo deus. The new model will retain some human features but will have enhanced mental and physical abilities. ${ }^{69}$ The second type, 'Data religion', merits a little more explanation. Humans have 'completed their cosmic tasks, and they should now pass the torch on to entirely new kinds of entities' ${ }^{70}$ The central premise of this religion, also called 'Dataism', is that 'the universe consists of data flows, and the value of any phenomenon or entity is determined by its contribution to data processing' ${ }^{71}$

This builds upon his claim that humans, like other organisms, are algorithms and just one method for processing data. ${ }^{72}$ Dataism will mutate into a religion "where the supreme value is "information flow", ${ }^{73}$

This cosmic data processing system would be like God. It will be everywhere and will control everything, and humans are destined to merge into it. This vision is reminiscent of some traditional religious visions. Thus Hindus believe that humans can and should merge into the universal soul of the cosmos - the atman. Christians believe that after death saints are filled by the infinite grace of God, whereas sinners cut themselves off from His presence. Indeed, in Silicon Valley the Dataist prophets consciously use traditional messianic language. For example, Ray Kurzweil's book of prophecies is called The Singularity is Near, echoing John the Baptist's cry: 'the kingdom of heaven is near' (Matthew 3:2). ${ }^{74}$

\footnotetext{
60 Matthew 15:27.

61 Harari, Homo Deus, 181.

62 Ibid, 101.

63 Ibid, 282, 328, 363.

64 Ibid, 115. Thus, 'God will no longer be conceived widely as an objective spiritual being one who personally hears and answers prayers, and who guides human history from behind the scenes': Geering, World to Come, 87.

65 Harari, Homo Deus, 200.

66 Ibid, 21.

67 Ibid, 85, 319, 328, 368, 397. An algorithm is 'a methodical set of steps that can be used to make calculations, resolve problems and reach decisions': ibid, 83 .

68 Ibid, 349.

69 Ibid, ch 10 .

70 Ibid, 351.

71 Ibid, 307.

72 Ibid, 368.

73 Ibid, 380.

74 Ibid, 381.
} 
The passage above mentions the Singularity. This rather mysterious thing, according to its principal interpreter, 'represents a discontinuity in human progress that would be fundamentally opaque until it occurred'. ${ }^{75}$ Yet some indication of it will be, as Kurzweil predicts, a merging of humans with machines to, once more, through innovation and advanced technology, enable mankind to attain immortality. Critics are not slow to mock this lofty talk as tantamount to 'a quasi-religion for the technical elite and a kind of "rapture for the nerds"" ${ }^{76}$

Turning now to law, the march of technology will not leave this untouched either. There will likely emerge new devices or resources to gather and test evidence, in the same way that DNA revolutionized forensic science. Perhaps we will see machines that can read minds - or at least correlate patterns of brain activity to certain culpable or non-culpable desires or intent. ${ }^{77}$

My Otago colleague, Colin Gavaghan, recently wrote about what he calls 'technoregulatory mechanisms' (TRMs). ${ }^{78}$ This term refers to design structures or devices that render noncompliance practically or literally impossible. The recent use of 'antihomeless spikes' outside residential complexes in London are an example. ${ }^{79}$ The use of architecture to impose rules and secure conformity is not new (think of a simple lock), ${ }^{80}$ but, again, technology elevates this to a new level. The use of computer-based impossibility structures - digital locks or filters - to prevent criminal or anti-social conduct before it occurs might be thought to be a boon. But there is also a troubling aspect to this. 'If we are regulated', asks Roger Brownsword, 'so that we can only do the right thing, does it matter that we lose the opportunity to do the wrong thing?'81

The potential for the state to design TRMs to stifle religions it considers are harmful to society is not far-fetched. The state could, for instance, set internet filters so that not just pornography is thwarted, but also 'proselytism' or 'hate speech' by religious groups that the government adjudges to be pernicious. (Indeed, that day may not be too far away). ${ }^{82}$ A liberal state would necessarily be departing from its inbuilt commandment

75 Ford, Rise of the Robots, 229-230. Kurzweil's book is The Singularity is Near: When Humans Transcend Biology (New York, Viking, 2005).

76 Ford, Rise of the Robots, 230.

77 Harari vigorously attacks the notion that there is anything constituting 'the mind' beyond algorithmic responses of cerebral neurons: Homo Deus, 107-119. Intrusion into our minds might necessitate legal protection, perhaps in the form of a 'right to mental self-determination': see Jan Christopher Bublitz, 'If a Man's True Palace is his Mind, What is its Adequate Protection? On a Right to Mental Self-determination and Limits of Interventions into Other Minds' in Bibi van den Berg and Laura Klaming (eds), Technologies on the Stand: Legal and Ethical Questions in Neuroscience and Robotics (Nijmegen, Wolf Legal, 2011) ch 4.

78 Colin Gavaghan, 'Lex Machina: Techno-regulatory Mechanisms and "Rules by Design"' (2017) 15 Otago L Rev 123.

79 Ibid, 123.

80 Ibid, 126.

81 Ibid, 134 (quoting Brownsword, Rights, Regulation and the Technological Revolution (Oxford, Oxford University Press, 2008) 256).

82 See the report prepared by Dan Shefet for UNESCO entitled 'Policy Options and Regulatory Mechanisms for Managing Radicalization on the Internet' (Paris, 30 September 2016) <https://en.unesco.org/sites/default/files/rapport_dan_shefet.pdf>. I am grateful to Colin Gavaghan for alerting me to this report. Policy Recommendation 4 (ibid, 112) reads: 'A theory 


\section{Research handbook on law and religion}

to be neutral towards religion. Richard Thaler and Cass Sunstein in their influential book, Nudge, warned that 'the government must avoid deliberate nudging' in the particular sense that its 'choice architecture' cannot favour, inter alia, one religion over another and thus it may not "encourage people to join a "Pray to Jesus More Tomorrow" plan'.83 This is, I suppose, comforting. But some nations make no pretence to be members of the international liberal democratic club. Moreover, even if the country is a liberal state, it might rationalize its actions as directed not at the religion itself, but only its members' activities in so far as their conduct becomes seditious or anti-social. A further concern is that the TRMs may be imposed by powerful private actors such as Google or Facebook to limit religious speech. ${ }^{84}$

The insertion of tiny microchips and the laser inscription of subcutaneous tattoos for security reasons - to avert, if not eliminate, fraud in everyday commerce or to smooth trans-border movements - is another possibility. This would probably pass without significant demur by most citizens: who could rationally object to a painless, once-only, free, invisible, tiny inconvenience that would effectively combat fraud? And yet it would be a matter of vehement objection by religionists who view such marking of their bodies as a betrayal of their faith. ${ }^{85}$

In the best tradition of science fiction films such as Arrival and District 9, what ought to be our response if extra-terrestrial beings should one day land? ${ }^{86}$ If they wish to reside here - and assuming they have not subjugated the entire human race - we might ponder how we should engage with their religion (assuming, again, that religion is intrinsic to all intelligent life). Would we grant them freedom of religion? Would we allow them to evangelize and woo earthlings to their faith? Would the proselytizing religions be free to attempt to evangelize the aliens (assuming they have souls)?

As for the relationship between Law and Religion, it is hard to see much in the way of innovation there. If religion has not withered as the Enlightenment thinkers hoped,

allowing "preventive blocking" or "blocking by reference to potential radicalization" must necessarily be developed albeit with full recognition of the caution that such an effort requires. This challenge will obviously be demanding and controversial, but nonetheless imperative. The problem may be illustrated by sites like "Inspire" (authored by Al Qaida) or "Dabiq" (Isis). A substantial portion of content on these and similar sites may not be qualified as "radicalizing" or otherwise. Yet the sites as such should be blocked on the basis of an "anticipation or prevention theory" due to their general association with radicalization'.

${ }^{83}$ Nudge: Improving Decisions About Health, Wealth, and Happiness (New Haven, Yale University Press, 2008) 246.

84 Gavaghan, 'Lex Machina', 139. The UNESCO report, 'Managing Radicalization on the Internet', would subject its proposed regulatory regime upon ISPs (see Policy Recommendation 1).

85 Here one thinks of Christians who take the injunction not to succumb to receiving the 'mark of the Beast' on their forehead or hand (Revelation 13:16-17; 14: 9-11) literally and very seriously - indeed, to the point of martyrdom. On the meaning of the phrase, see, eg, Jonathan Kirsch, A History of the End of the World (San Francisco, HarperCollins, 2006) 70-71.

86 See Klara Anna Capova, 'The Detection of Extraterrestrial Life: Are We Ready?' in Douglas A Vakoch (ed), Astrobiology, History, and Society: Life Beyond Earth and the Impact of Discovery (Springer 2013) ch 14; Linda Besner, 'Do Aliens Have Souls?', Hazlitt, 4 February 2013; 'Extra-Terrestrial IT Protocols: What Happens if Aliens Land on Earth?' <https:// diamondit.pro/innovation/extra-terrestrial-protocols-happens-aliens-land-earth/>. 
and the sociologists once upon a time forecast, then there will be something there to regulate. It is even harder to imagine that something we recognize as law - rules, conventions and norms that govern human activity and an accompanying apparatus to monitor and enforce these - will have become redundant. Given the persistence of both religion and law then, the number of possible relationships between the two will remain extant: co-option of one by the other, separation, and various modes of smooth or uneasy cooperation.

\section{CONCLUSION}

Some areas will continue to receive the lion's share of scholarly traffic. Like the Strait of Hormuz or the Bosphorus, the right to religious freedom (in all its multifarious dimensions) and the constitutional response to institutional religion will be busy shipping lanes. I have alluded to three areas of religio-legal concern where more academic analysis would be salutary. Similar to the under-utilized inland waterways of vast nations such as India and Brazil, ${ }^{87}$ they languish through neglect. Finally, I ventured some tentative prognostications on what might occupy Law and Religion scholars in the decades ahead. My rather hubristic effort at cartography of this terra incognito is just that, but I console myself that all cartography is subjective and expresses the cultural assumptions and worldview of its creator. ${ }^{88}$

In the life of the law, the sub-discipline called Law and Religion is but an infant. It has begun to crawl and even take a few wobbly steps. Those who are its handmaids, so to speak, are attending to its development with due care. I think there is a bright future ahead for Law and Religion, but then I would say that. I like to think I follow in the optimistic footsteps - albeit compared to him, just a bit player ${ }^{89}$ - of Harold Berman:

[We have what] might be called an eschatological perspective. Living between two worlds, we experience the dying of the old orders of law and religion and anticipate their regeneration. ${ }^{90}$

87 See respectively GR Kumar, 'Understanding Importance of National Waterways', The Hans India, 20 September 2017 and 'Brazil's Waterways Could Decongest Gridlocked Roads', Financial Times, 9 September 2013.

88 Uri Friedman, '12 Maps that Changed the World - Is There Such a Thing as a Perfect Map?', The Atlantic, 30 December 2013: 'There are ... no perfect maps - just maps that (more-or-less) perfectly capture our understanding of the world at discrete moments in time'. Friedman was reviewing Jerry Brotton, A History of the World in Twelve Maps (Penguin 2012), whose thesis, crudely summarized, is that all maps are inevitably subjective.

89 Cf Matthew 3:11.

$90 \quad$ Interaction of Law and Religion, 16. 